\title{
Article \\ Governing Functionality of Silver Ion-Exchanged Photo-Thermo-Refractive Glass Matrix by Small Additives
}

\author{
Yevgeniy Sgibnev*(D, Nikolay Nikonorov and Alexander Ignatiev \\ Faculty of Photonics, ITMO University, 199034 St Petersburg, Russia; nikonorov@oi.ifmo.ru (N.N.); \\ ignatiev@oi.ifmo.ru (A.I.) \\ * Correspondence: sgibnevem@gmail.com
}

check for updates

Citation: Sgibnev, Y.; Nikonorov, N.; Ignatiev, A. Governing Functionality of Silver Ion-Exchanged Photo-Thermo-Refractive Glass Matrix by Small Additives. Appl. Sci. 2021, 11, 3891. https://doi.org/ 10.3390/app11093891

Academic Editor: Jesús Liñares Beiras

Received: 14 March 2021

Accepted: 20 April 2021

Published: 25 April 2021

Publisher's Note: MDPI stays neutral with regard to jurisdictional claims in published maps and institutional affiliations.

Copyright: (c) 2021 by the authors. Licensee MDPI, Basel, Switzerland. This article is an open access article distributed under the terms and conditions of the Creative Commons Attribution (CC BY) license (https:// creativecommons.org/licenses/by/ $4.0 /)$.

\begin{abstract}
In this study, the influence of small additives on the spectral and optical properties of $\mathrm{Na}^{+}-$ $\mathrm{Ag}^{+}$ion-exchanged silicate glass is presented. Polyvalent ions, for example, cerium and antimony, are shown to reduce silver ions to atomic state and promote the growth of photoluminescent silver molecular clusters and plasmonic silver nanoparticles. $\mathrm{Na}^{+}-\mathrm{Ag}^{+}$ion-exchanged and heat-treated glasses doped with halogen ions, such as chlorine or bromine, exhibit formation of photo- and thermochromic $\mathrm{AgCl}$ or $\mathrm{AgBr}$ nanocrystals. Growth of a silver nanoisland film on the glass surface was observed in the case of undoped sample. The presented results highlight the vital role of small additives to control properties of the silver nanostructures in $\mathrm{Na}^{+}-\mathrm{Ag}^{+}$ion-exchanged glasses. Possible applications of $\mathrm{Na}^{+}-\mathrm{Ag}^{+}$ion-exchanged glass ceramics include but are not limited to biochemical sensors based on surface-enhanced Raman scattering phenomena, temperature and overheating sensors, white light-emitting diodes, and spectral converters.
\end{abstract}

Keywords: ion exchange; silver; photo-thermo-refractive glass; silver nanoparticles; silver molecular clusters; silver bromide nanocrystals

\section{Introduction}

Over time, glasses have occupied a particular place among various optical materials due to their wide range of transparency, easily tuned properties, and workability. Recently, research has focused more on the development of new composite glassy materials, e.g., including materials doped with nanoparticles and/or nanocrystals. Today, functional glasses that actively interact with light are required. An example of functional optical material is photo-thermo-refractive (PTR) glass based on a sodium-zinc-aluminosilicate matrix containing halogens (fluorine and bromine) and doped with silver, antimony, and cerium oxides [1,2]. The refractive index of PTR glass is changed after exposure to UV light and the subsequent thermal treatment in the vicinity of the glass transition temperature. The latter step leads to the formation of silver nanoparticles (SNPs) playing the role of nucleation centers for $\mathrm{NaF}$ nanocrystals in the glass host, causing variations in the refractive index. Mechanisms of photo-thermo-induced crystallization in PTR glass were studied in detail and reported in [3,4]. Currently, phase holograms recorded in PTR glass are used as line-narrowing and stabilizing filters, spectral and spatial filters, compressors for femtoand picoseconds laser beams, spectral beam combiners, high-power beam splitters, etc. Although PTR glass was developed as a photosensitive medium for recording volume Bragg gratings, recent studies showed that it is a polyfunctional material that can combine the properties of holographic, laser, and photoetchable media [1,2,5-8]. In this work, we demonstrate that the functionality of PTR glass matrix can be substantially extended via the formation of silver nanostructures inside the glass or on its surface.

Silver can be introduced in a silicate glass matrix by adding silver-containing chemicals into the glass batch, via ion implantation or via ion exchange (IE). Due to the low solubility of silver in a silicate matrix, the first approach allows embedding up to $0.2 \mathrm{~mol} \% \mathrm{Ag}_{2} \mathrm{O}$. Ion implantation requires special sophisticated equipment, and only very thin layers can 
be modified with the method, whereby the typical thickness of the silver-enriched region is below $2 \mu \mathrm{m}[9,10]$. The IE technique, on the other hand, is characterized by simplicity, flexibility, and applicability for mass production. For example, $\mathrm{Na}^{+}-\mathrm{K}^{+} \mathrm{IE}$ is used for glass strengthening on an industrial scale for producing cover glass for smartphones [11]. The method is based on the substitution of alkali $\left(\mathrm{Na}^{+}, \mathrm{K}^{+}, \mathrm{Rb}^{+}, \mathrm{Cs}^{+}\right)$or transition $\left(\mathrm{Ag}^{+}\right.$, $\mathrm{Cu}^{+}, \mathrm{Tl}^{+}$) metal ions from glass by another one from the salt melt, metal film, or another source [12-14]. A comparison of ion implantation and ion exchange technologies for modification of glass is shown in Table 1 .

Table 1. Comparison of the ion implantation and ion exchange technologies.

\begin{tabular}{|c|c|c|}
\hline Parameter & Ion Exchange & Ion Implantation \\
\hline Simplicity/complication & Very simple and flexible technology & Requires sophisticated equipment \\
\hline Applications of modified glass & $\begin{array}{l}\text { Optical waveguides; glass strengthening; } \\
\text { nanostructuring }\end{array}$ & $\begin{array}{l}\text { Optical waveguides; glass hardening; } \\
\text { nanostructuring }\end{array}$ \\
\hline Variety of metal nanostructures & $\begin{array}{l}\text { Limited to copper and silver } \\
\text { nanostructures due to possibility of ions } \\
\text { to effectively exchange with alkali ions } \\
\text { from a glass substrate } \\
\text { High chemical durability to salt melt; }\end{array}$ & $\begin{array}{l}\text { Depends on ion source: } \mathrm{Ag}, \mathrm{Cu}, \mathrm{Ni}, \mathrm{Co} \text {, } \\
\mathrm{Ti}, \mathrm{Cr} \text {, and } \mathrm{Zn} \text { nanoparticles were } \\
\text { obtained and studied in glasses }\end{array}$ \\
\hline Requirements for glass substrate & $\begin{array}{l}\text { limited to } \\
\text { alkali-containing glasses }\end{array}$ & No requirements \\
\hline Thickness of the glass modified region & $\begin{array}{l}\text { The range is very wide and depends on } \\
\text { particular application, typically in the } \\
\text { range from few to tens of microns }\end{array}$ & Typically, below $2 \mu \mathrm{m}$ \\
\hline Temperature during modification & $\begin{array}{l}\text { Should be at least above melting } \\
\text { temperature of salt melt; in most cases, } \\
\text { temperature is in the range } 250-450{ }^{\circ} \mathrm{C} \text {. }\end{array}$ & Low-temperature processing \\
\hline Reproducibility & Excellent & Excellent \\
\hline Allows overcoming solubility of dopant & Yes & Yes \\
\hline High-scale production capability & Already used for mass production & Already used for mass production \\
\hline $\begin{array}{l}\text { Allows overcoming solubility of dopant } \\
\text { in glass matrix }\end{array}$ & Yes & Yes \\
\hline
\end{tabular}

It must be noted that most research papers devoted to the study of silver nanostructures formed in ion-exchanged glasses focused on the influence of the ion exchange (concentration of silver in salt melt, temperature, and duration) and subsequent heat treatment (temperature and duration) parameters, while glass composition and influence of the glass additives have not received much attention. As it is shown further, these uncharacterized factors play a key role in determining the properties of silver nanostructures and, consequently, the functionality of the glass doped with them. This research deals with the influence of typical additives of PTR glass on the spectral and optical properties of $\mathrm{Na}^{+}-\mathrm{Ag}^{+}$ion-exchanged layers. However, as PTR glass is based on the well-known and widely used sodium-aluminosilicate matrix, our results can be extended to other silicate glasses.

\section{Materials and Methods}

Glass blocks of samples based on the $14 \mathrm{Na}_{2} \mathrm{O}-3 \mathrm{Al}_{2} \mathrm{O}_{3}-5 \mathrm{ZnO}-71.5 \mathrm{SiO}_{2}-6.5 \mathrm{~F}(\mathrm{~mol} . \%)$ composition were synthesized in a furnace at $1500{ }^{\circ} \mathrm{C}$ in air atmosphere using a platinum crucible and mechanical stirrer. The glass transition temperature of the samples was determined using an STA 449F1 Jupiter (Netzsch, Germany) differential scanning calorimeter at a heating rate of $10 \mathrm{~K} / \mathrm{min}$. For the optical study, planar polished samples with a thickness of 0.9-1.0 mm were prepared. $\mathrm{Na}^{+}-\mathrm{Ag}^{+}$IE was conducted by immersing glass samples in a bath with a melt of silver and sodium nitrates (5 mol.\% $\mathrm{AgNO}_{3} / 95 \mathrm{~mol} . \% \mathrm{NaNO}_{3}$ ) at $320^{\circ} \mathrm{C}$. Absorbance spectra were recorded with a double-beam spectrophotometer Lambda 650 (Perkin-Elmer). The emission spectra were measured inside an integrated sphere using 
a photonic multichannel analyzer (PMA-12, Hamamatsu, Japan) at room temperature. XRD characterization was performed using a Rigaku Ultima IV X-ray diffractometer.

\section{Results and Discussion}

\subsection{Spontaneous Growth of Silver Nanoparticles on the Surface of Ion-Exchanged} Photo-Thermo-Refractive Glass Heat-Treated in Air Atmosphere

Plasmonic metal nanoparticles have attracted significant interest in photonics due to their unique optical properties. Potential applications of metal nanoparticles include but are not limited to biosensing [15], surface-enhanced Raman spectroscopy (SERS) [16], solar cells [17], targeted drug delivery [18], saturable absorbers [19], and photocatalysis [20]. SERS is one of the most widely studied applications of the metal nanoparticles. The phenomenon was firstly observed from pyridine molecules adsorbed on roughened silver electrodes by Fleischmann et al. in 1974 [21]. Despite SERS mechanisms still being under discussion, it has become a powerful and ultrasensitive tool due to the possibility of enhancing Raman scattering magnitude by $10-14$ orders. This allows one to detect even a single molecule [22,23].

Roughened metal surfaces can be obtained in different ways, including thermal, electron beam, chemical, and plasma deposition methods. Recently, it was shown that a SERS-active silver nanoisland film (SNIF) can be easily formed on the surface of $\mathrm{Na}^{+}-\mathrm{Ag}^{+}$ ion-exchanged glasses. Two different approaches were developed to grow SERS-active SNIF on a glass surface (Figure 1). The first is based on the growth of SNPs in the ionexchanged glass layers with subsequent chemical etching to obtain SNPs directly on the glass surface $[24,25]$. The concentration of NPs on glass surface can be controlled by silver content in a salt melt during the IE process and by the thickness of the etched glass layer. The second approach involves thermal treatment of $\mathrm{Na}^{+}-\mathrm{Ag}^{+}$ion-exchanged glass in a reducing atmosphere, for example, hydrogen atmosphere or water vapor [26,27]. Growth of SNPs in the subsurface glass region can be suppressed by low temperature of the treatment (at least $100{ }^{\circ} \mathrm{C}$ below the glass transition temperature). Moreover, the poling technique can be applied to $\mathrm{Na}^{+}-\mathrm{Ag}^{+}$ion-exchanged glasses to obtain single NPs on the glass surface $[28,29]$. It should be noted that the considered approaches show similar performance as SERS-active substrates.
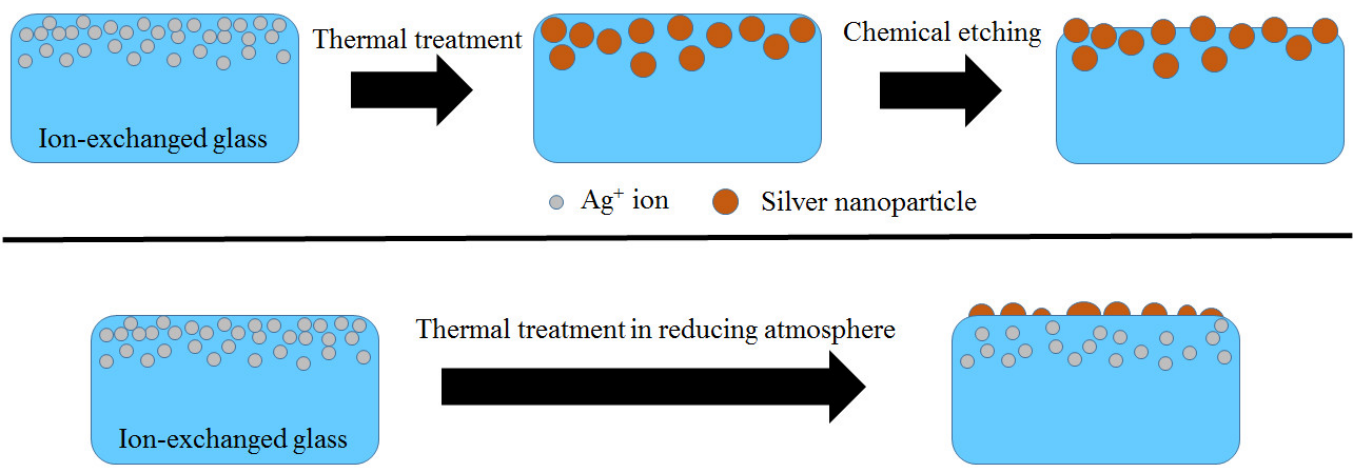

Figure 1. Schemes of two processes of formation of SNIF at the surface of $\mathrm{Na}^{+}-\mathrm{Ag}^{+}$ion-exchanged glass.

Our preliminary research revealed the spontaneous growth of SNIF at the surface of $\mathrm{Na}^{+}-\mathrm{Ag}^{+}$ion-exchanged undoped matrix-based PTR glasses. To our best knowledge, this is the first observation of growth of SNIF at the surface of ion-exchanged glass after heat treatment in air. Figure 2 shows photos of BK-7 optical glass and PTR matrix-based glass with no dopants (hereafter denoted as PTR-M; see Table 2) after the $\mathrm{Na}^{+}-\mathrm{Ag}^{+}$IE and heat treatment at a temperature of $50{ }^{\circ} \mathrm{C}$ above corresponding $\mathrm{T}_{\mathrm{g}}$ values. BK-7 exhibited the yellowish coloration typical for most silver ion-exchanged and heat-treated glasses, which results from absorption of the SNPs formed in silver-enriched glass layers [30,31]. PTR-M glass, on the contrary, possessed no coloration, due to the absence of electrons for reducing 
silver ions inside the glass [32]. Moreover, a gray semitransparent film was observed on the PTR-M glass surface.

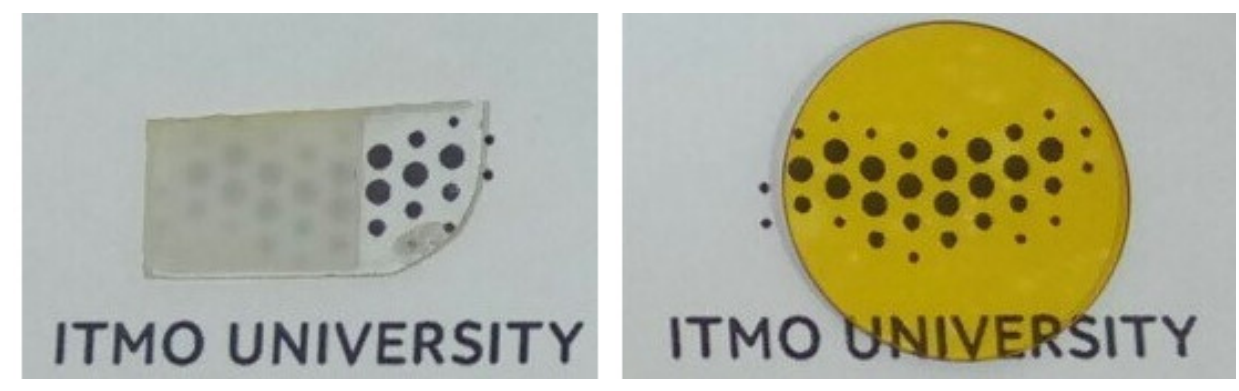

Figure 2. Photo of the PTR-M glass sample (left) after $\mathrm{Na}^{+}-\mathrm{Ag}^{+} \mathrm{IE}$ and heat treatment at $500{ }^{\circ} \mathrm{C}$ for $3 \mathrm{~h}$ (the resulting surface film was partially removed) and of BK-7 glass ion-exchanged and heat-treated at $600{ }^{\circ} \mathrm{C}$ for $3 \mathrm{~h}$ (right).

Table 2. Batch concentration of additives in the studied PTR glass samples.

\begin{tabular}{ccc}
\hline Glass & $\mathbf{S b}_{\mathbf{2}} \mathbf{O}_{5}, \mathbf{m o l} . \%$ & Br, mol.\% \\
\hline PTR-M & 0 & 0 \\
PTR-Br & 0 & 1.4 \\
PTR-Sb2 & 0.002 & 0 \\
PTR-Sb4 & 0.004 & 0 \\
PTR-Sb10 & 0.01 & 0 \\
\hline
\end{tabular}

For further detailed research, PTR-M glass with no dopants was studied. Silver ions were introduced by immersing the PTR glass samples into the bath containing a mixture of $5 \mathrm{AgNO}_{3} / 95 \mathrm{NaNO}_{3}(\mathrm{~mol} . \%)$ at $320^{\circ} \mathrm{C}$ for $15 \mathrm{~min}$. Ion-exchanged PTR glass samples were then heat-treated in air at temperatures in the range $350-500{ }^{\circ} \mathrm{C}$, with a treatment duration of up to $7 \mathrm{~h}$. An $\mathrm{Na}^{+}-\mathrm{Ag}^{+}$ion-exchanged glass layer was mechanically removed from one side of the samples prior the heat treatment. Glass samples were placed in a muffle furnace with the silver-containing side facing upward.

Figure 3 shows absorbance spectra of the ion-exchanged PTR-M glass samples heattreated in different conditions. The absorption band peak at $445 \mathrm{~nm}$, related to the growth of SNIF on the ion-exchanged PTR-M glass surface, was observed already after the heat treatment for $15 \mathrm{~min}$ at $350{ }^{\circ} \mathrm{C}$ (Figure 3a). The increase in absorption amplitude, red shift of the absorption peak, and emergence of the second band around $355 \mathrm{~nm}$ occurred with a longer heat treatment duration. An analogous dependence of the absorbance spectra on the heat treatment time was obtained for the samples heat-treated at 400 and $450{ }^{\circ} \mathrm{C}$ (Figure $3 \mathrm{~b}, \mathrm{c}$ ). Similar changes in the absorbance spectra of SNPs dispersed in water solution were observed as a function of increasing size from 46 to $287 \mathrm{~nm}$ by Kinnan and Chumanov [33]. The authors assigned the observed changes to quadrupolar, octupolar, and hexadecapolar plasmon modes in SNPs with a size of $128-287 \mathrm{~nm}$. As heat treatment temperature governs the kinetics of redox reactions and diffusion process of SNPs growth, it also influences the mean size and size distribution of SNPs. The heat treatment at $500{ }^{\circ} \mathrm{C}$, i.e., above the glass transition temperature $\left(464^{\circ} \mathrm{C}\right.$ for PTR-M glass), resulted in almost structureless absorbance spectra due to very broad and overlapped bands.

To confirm that neither silver molecular clusters (SMCs) nor SNPs were formed in the ion-exchanged PTR-M glass during the heat treatment, the following experiment was conducted: a sample of the $\mathrm{Na}^{+}-\mathrm{Ag}^{+}$ion-exchanged PTR-M glass was repeatedly heattreated at $500{ }^{\circ} \mathrm{C}$. The SNIF formed on the PTR glass surface was removed mechanically by polishing the sample for 3-5 s, and absorption spectra were recorded after each cycle. The absorbance spectra obtained during this experiment are shown in Figure $4 \mathrm{a} . \mathrm{Na}^{+}-\mathrm{Ag}^{+}$IE in PTR glass is known to induce a long-wavelength shift of the UV absorption edge [34]. The 
reason for the shift is strong absorption of the introduced silver ions that are characterized by the absorption envelope peak at $225 \mathrm{~nm}$ [35]. Thus, in contrast to the IE effect on absorbance spectra, a short-wavelength shift of the UV absorption edge was observed in the heat-treated samples. The spectra of the ion-exchanged and heat-treated PTR-M sample after removing SNIF showed no absorbance in the range above $300 \mathrm{~nm}$, where the absorption bands of SMCs and SNPs in PTR glass are located [36]. This result also proved that all the features observed in the spectra presented in Figure 3 are related to SNIF formed on the PTR-M glass surface. Location of the UV absorption edge of the $\mathrm{Na}^{+}-\mathrm{Ag}^{+}$ ion-exchanged PTR-M glass is determined by the absorption of $\mathrm{Ag}^{+}$ions [37]. Thus, it is possible to roughly estimate the integral silver concentration in the heat-treated samples compared to nontreated ones using the Beer-Lambert law. The differential absorbance spectra obtained by subtracting the spectrum of the as-synthesized sample from the others are shown on Figure $4 \mathrm{~b}$. The differential absorbance decreased more than eightfold at $255 \mathrm{~nm}$, from $\sim 2.6$ to $\sim 0.3$ after $1 \mathrm{~h}$ of heat treatment at $500{ }^{\circ} \mathrm{C}$. Further treatment led to a slower decrease in differential absorbance, down to $\sim 0.1$. Thus, heat treatment at $500{ }^{\circ} \mathrm{C}$ induced out-diffusion of silver ions to the glass surface with formation of SNIF, resulting in a $95 \%$ reduction in the total number of silver ions in the PTR-M glass sample compared to the nontreated ion-exchanged sample.
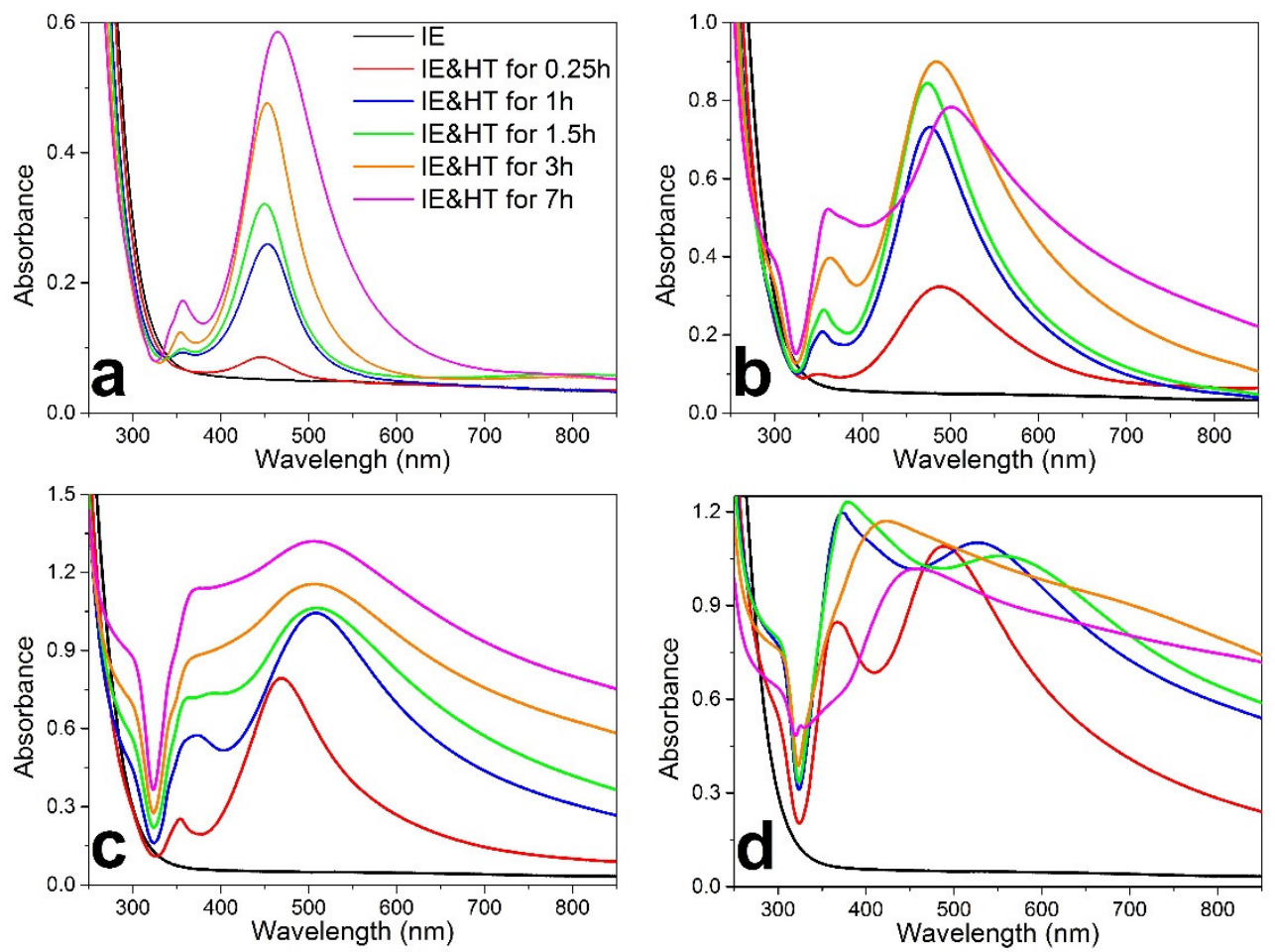

Figure 3. Absorbance spectra of PTR-M glass sample after the $\mathrm{Na}^{+}-\mathrm{Ag}^{+}$IE and with SNIF obtained at $350{ }^{\circ} \mathrm{C}(\mathbf{a}), 400{ }^{\circ} \mathrm{C}(\mathbf{b}), 450{ }^{\circ} \mathrm{C}(\mathbf{c})$, and $500{ }^{\circ} \mathrm{C}$ (d) for different durations, indicated by colors.

XRD analysis of the PTR glass samples heat-treated at different temperatures for $3 \mathrm{~h}$ revealed characteristic peaks for metallic silver (Figure 5), confirming that the observed SNIF consisted of silver nanoparticles. SEM analysis of the of the ion-exchanged and heattreated PTR-M glass surface revealed the presence of isolated nanometer and micrometer particles (Figure 6). SNIF formed at $350{ }^{\circ} \mathrm{C}$ consisted of nanoparticles of different shapes (triangle, square, and rectangular), while, at higher temperatures, nanoparticles had only spherical shape. The latter should be related to the melting of small SNPs during the heat treatment at temperatures above $400{ }^{\circ} \mathrm{C}$ [38-40]. Moreover, SEM analysis showed that the mean diameter of silver particles in the SNIF increased from 140 to $320 \mathrm{~nm}$ with heat treatment temperature increasing from 350 to $500{ }^{\circ} \mathrm{C}$. This result correlates with 
the changes in absorbance spectra presented in Figure 3. The phase retardation of the electromagnetic field inside large particles led to the plasmon modes of higher multipole orders (quadrupolar, octupolar, and hexadecapolar) observed in the spectra [41].
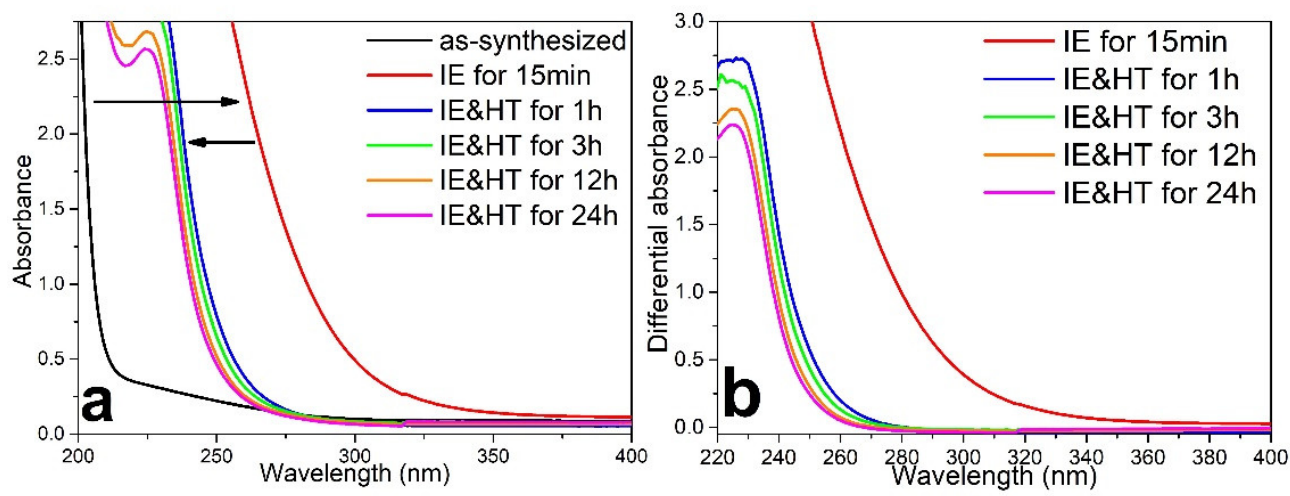

Figure 4. (a) Absorbance spectra of as-synthesized and $\mathrm{Na}^{+}-\mathrm{Ag}^{+}$ion-exchanged PTR-M glass samples after heat treatment at $500{ }^{\circ} \mathrm{C}$ for different durations measured after removing the SNIF. (b) The differential absorbance spectra obtained by subtracting the spectrum of the as-synthesized sample from the others.

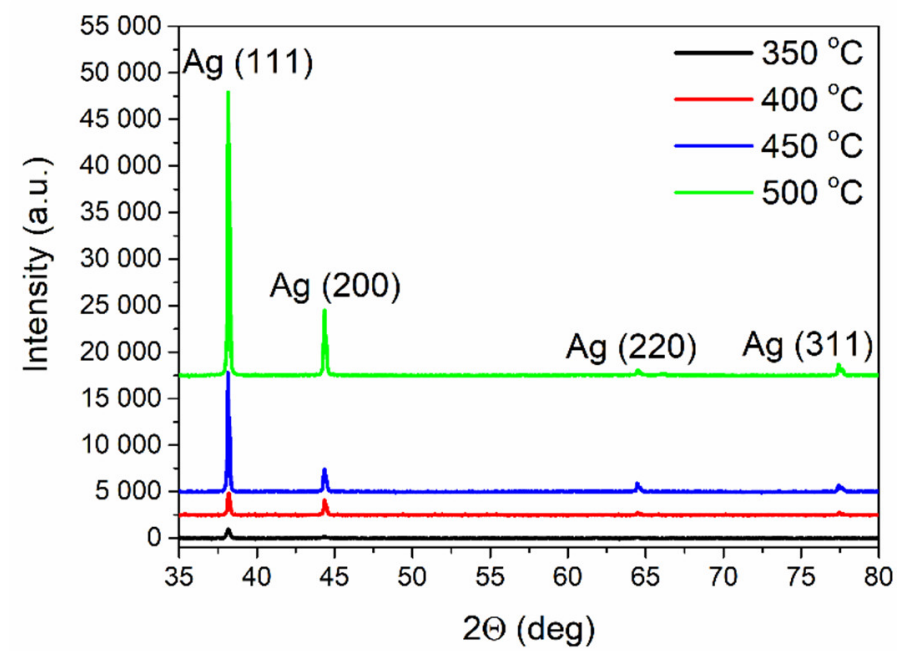

Figure 5. XRD spectra of the ion-exchanged and heat-treated for $3 \mathrm{~h}$ PTR-M glass samples with SNIF.

Considering possible mechanisms of the spontaneous growth of SNIF on the ionexchanged PTR glass surface, the main question concerns the source of electrons for reducing silver ions. The mechanism of silver ion reduction by water vapor in a wet argon atmosphere responsible for growth of SNIF on the surface of $\mathrm{Na}^{+}-\mathrm{Ag}^{+}$ion-exchanged borosilicate glass was suggested by Kaganovskii et al. [42]. The authors proposed silverproton exchange with the formation of silver oxide that thermally decomposes further to silver and oxygen.

$$
\begin{gathered}
\equiv \mathrm{Si}-\mathrm{O}-\mathrm{Ag}^{+}+\frac{1}{2} \mathrm{H}_{2} \mathrm{O} \leftrightarrow \equiv \mathrm{Si}-\mathrm{O}-\mathrm{H}^{+}+\frac{1}{2} \mathrm{Ag}_{2} \mathrm{O} . \\
\mathrm{Ag}_{2} \mathrm{O} \rightarrow 2 \mathrm{Ag}^{0}+\mathrm{O} .
\end{gathered}
$$

Other routes of silver reduction by glass impurities or nonbridging oxygen can be excluded considering that they would lead to coloration due to growth of SNPs inside the glass [43]. Thus, we suggest that SNIF on the surface of $\mathrm{Na}^{+}-\mathrm{Ag}^{+}$ion-exchanged PTR glass surface growth is the result of interaction with the water molecules always present in air. 
However, further research is needed to clarify the exact mechanism responsible for the growth of SNIF.
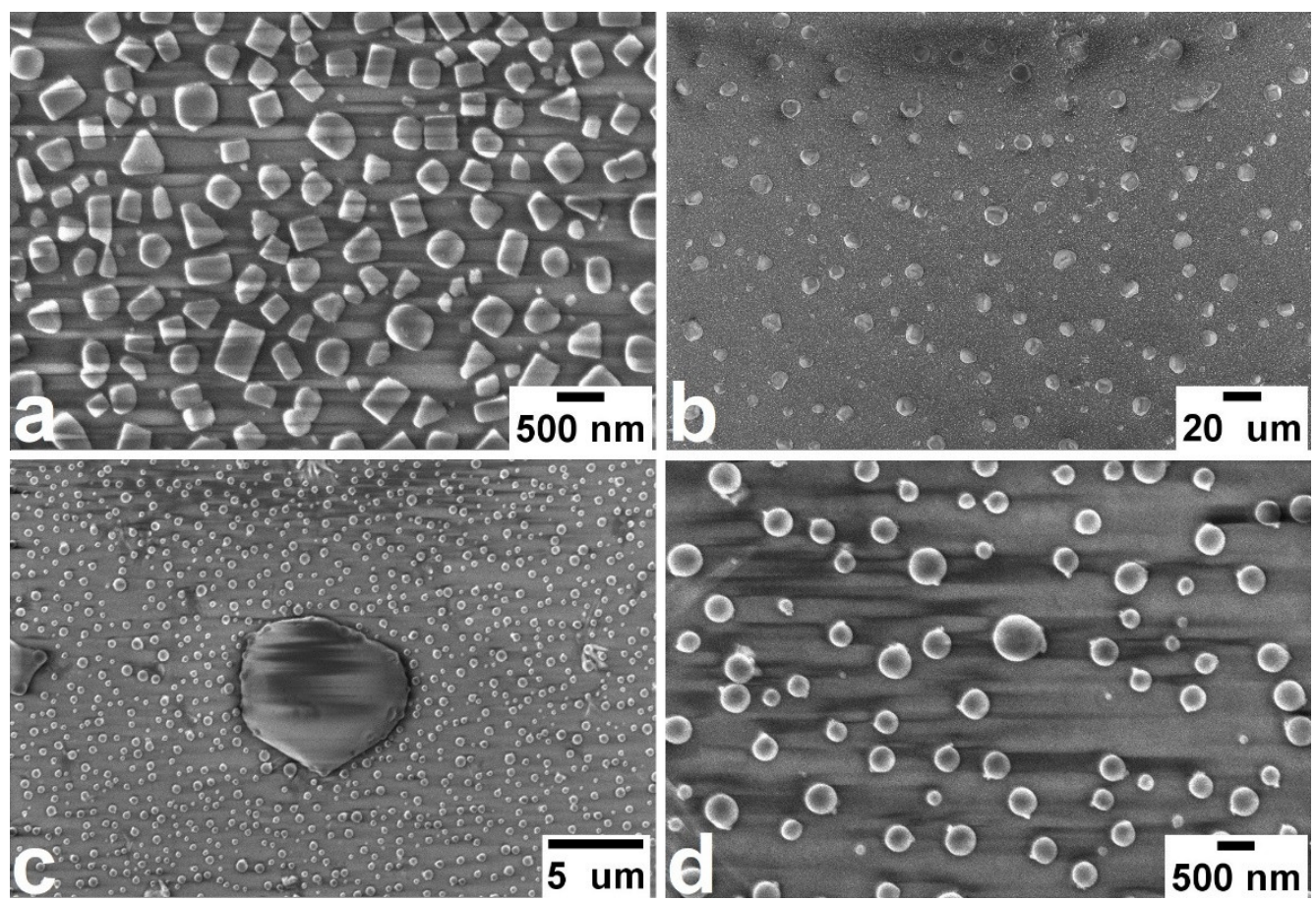

Figure 6. SEM image of the ion-exchanged PTR-M glass sample heat-treated at $350{ }^{\circ} \mathrm{C}(\mathbf{a})$ and $450{ }^{\circ} \mathrm{C}$ (b-d; various magnifications) for $3 \mathrm{~h}$.

A drop ( $~ 5 \mathrm{~mm}$ in diameter) of $8 \times 10^{-7} \mathrm{~mol} / \mathrm{L}$ R6G aqueous solution was deposited on the samples to investigate SERS-active properties of silver films on the surface of the PTR-M glass. The Raman spectra were measured after drying the R6G drop with the confocal Raman microscope (Renishaw); a red laser beam $(633 \mathrm{~nm})$ was focused at the sample surface with a $50 \times / 0.55$ micro-objective. A significantly enhanced spectrum was observed at surface with SNIF compared to pristine PTR-M glass (Figure 7a). As growth of SNIF on the PTR glass is a diffusion process, it can be grown using the same substrate in several cycles of thermal treatment and mechanical removal. This makes $\mathrm{Na}^{+}-\mathrm{Ag}^{+}$ ion-exchanged PTR glass functionalized with SNIF an attractive platform for developing reusable SERS sensors. Absorbance spectra of the $\mathrm{Na}^{+}-\mathrm{Ag}^{+}$ion-exchanged PTR-M glass with SNIF grown during several cycles of the heat treatment at $500{ }^{\circ} \mathrm{C}$ for $15 \mathrm{~min}$ and removing the film are shown on Figure $7 \mathrm{~b}$.

Thus, heat treatment at temperatures $350-500{ }^{\circ} \mathrm{C}$ of $\mathrm{Na}^{+}-\mathrm{Ag}^{+}$ion-exchanged PTR$\mathrm{M}$ glass with no dopants resulted in growth of SERS-active SNIF on the glass surface. Spectroscopic properties of SNPs on the glass surface can be controlled by changing the heat treatment temperature and time. $\mathrm{Na}^{+}-\mathrm{Ag}^{+}$ion-exchanged PTR glass can be used as a substrate for developing reusable biochemical sensors based on the SERS phenomenon.

\subsection{Photo- and Thermochromic Behavior of $\mathrm{Na}^{+}-\mathrm{Ag}^{+}$Ion-Exchanged Br-Doped Glasses}

In contrast to the PTR-M matrix glass with no dopants, $\mathrm{Na}^{+}-\mathrm{Ag}^{+}$ion-exchanged bromine-containing glass PTR-Br (see Table 2) revealed an additional long-wavelength shift of the UV edge of strong absorption after the heat treatment at $500{ }^{\circ} \mathrm{C}$ (Figure 8a). Silver bromide crystals are known to possess strong absorption in the UV and visible range, with absorption coefficients as high as $1000 \mathrm{~cm}^{-1}$ at $400 \mathrm{~nm}$, which may, thus, cause the long-wavelength shift [44]. Formation of AgBr nanocrystals in the ion-exchanged and heattreated PTR-Br glass samples was confirmed by XRD analysis. XRD peaks related to silver bromide were clearly observed for all ion-exchanged and heat-treated samples (Figure $8 b$ ). 
The mean diameter of AgBr nanocrystals calculated according to the well-known Scherrer equation increased from 5 to $10 \mathrm{~nm}$ upon extending the IE process from $15 \mathrm{~min}$ to $21 \mathrm{~h}$.
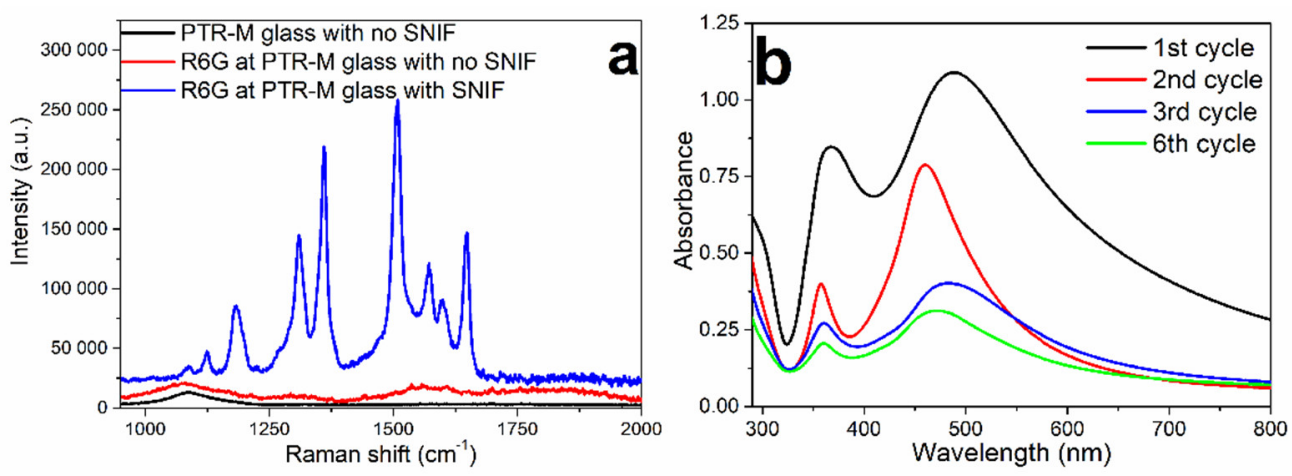

Figure 7. Raman spectra of PTR-M glass sample and R6G measured at ion-exchanged and heattreated at $350{ }^{\circ} \mathrm{C}$ for $3 \mathrm{~h}$ (a). Absorbance spectra of PTR-M glass with SNIF after several cycles of the heat treatment at $500{ }^{\circ} \mathrm{C}$ for $15 \mathrm{~min}$ and removing the film before the following heat treatment at the same parameters $(\mathbf{b})$.

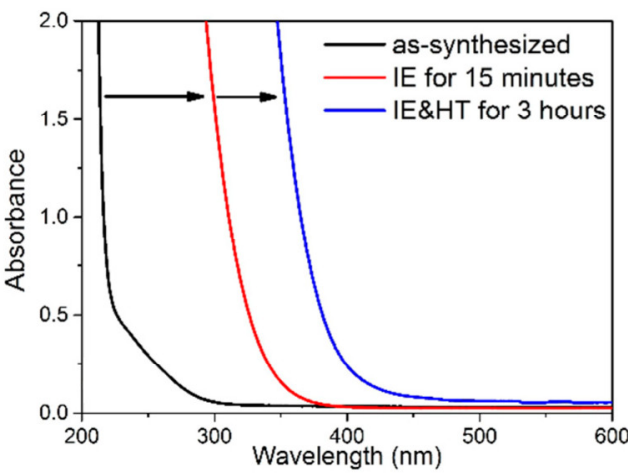

(a)

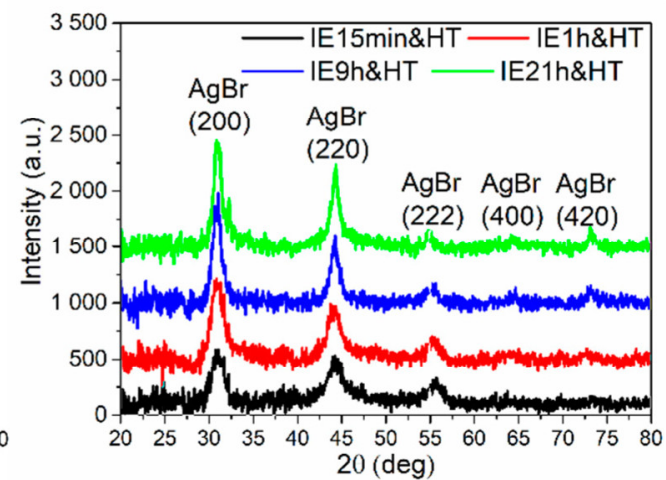

(b)

Figure 8. (a) Absorbance spectra of PTR-Br glass samples before and after the IE and heat treatment at $500{ }^{\circ} \mathrm{C}$ for $3 \mathrm{~h}$. (b) XRD patterns of PTR-Br glass samples ion-exchanged for different time and heat-treated at $500^{\circ} \mathrm{C}$ for $9 \mathrm{~h}$.

Silver bromide is known to decompose to silver and bromine under UV or visible light.

$$
\mathrm{AgBr} \stackrel{\mathrm{h} v}{\Rightarrow} \mathrm{Ag}^{0}+\mathrm{Br}^{0} .
$$

The process is used in photographic films; after exposure and decomposition of $\mathrm{AgBr}$, silver atoms aggregate further into colloidal particles and form a latent image, while the produced bromine volatilizes. In the case of a glass matrix, bromine atoms are unable to leave the matrix, which enables multiple cycles of recording and relaxation of color centers. This principle underlies photochromic glasses that reversibly changes transmission depending on the illumination [45]. In 1968, Garfinkel showed that photochromic glasses can be produced by $\mathrm{Na}^{+}-\mathrm{Ag}^{+}$ion exchange of borosilicate glasses doped with copper and bromine/chlorine [46]. Elliptical silver nanoparticles are known to be color centers in conventional photochromic glasses [47]. The experimental absorbance spectra consist of two broad bands corresponding to longitudinal and transverse plasmonic modes of elliptical SNPs. In order to study the photosensitivity of ion-exchanged PTR-Br glass, some samples were exposed to a mercury UV lamp $\left(\lambda_{\max }=365 \mathrm{~nm}\right)$. However, only the sample ion-exchanged for $21 \mathrm{~h}$ showed a noticeable change in absorbance (Figure 9). 

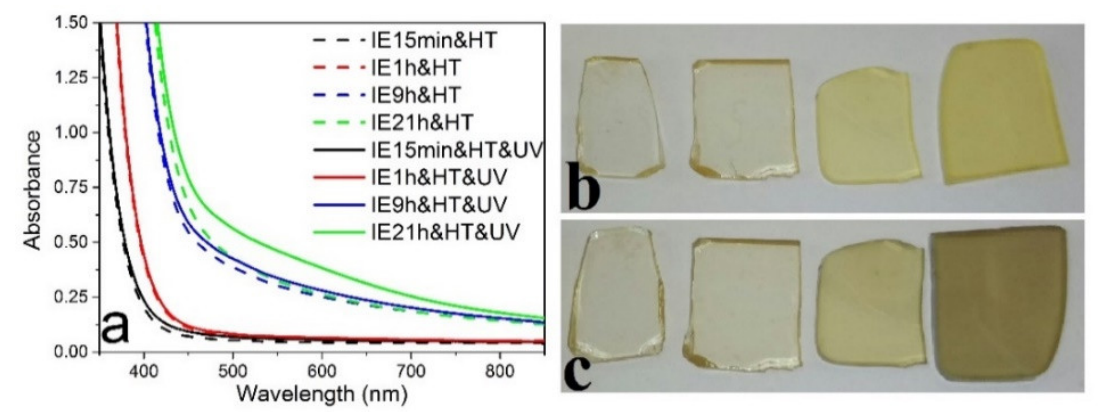

Figure 9. (a) Absorbance spectra of the ion-exchanged and heat-treated at $500{ }^{\circ} \mathrm{C}$ for $9 \mathrm{~h}$ PTR-Br glass samples before and after UV irradiation with a mercury lamp. (b) Photo of the samples before and (c) after the UV irradiation.

To enhance the formation of color centers in PTR-Br glass samples with AgBr nanocrystals, the samples were irradiated with a pulsed third-harmonic YAG:Nd laser $(\lambda=355 \mathrm{~nm}$, $\mathrm{f}=10 \mathrm{~Hz}$, pulse energy $20 \mathrm{~mJ}$, pulse duration $7 \mathrm{~ns}$ ). Intense laser $\mathrm{UV}$ light resulted in the growth of SNPs and, as a consequence, origin of a broad absorbance band in the visible range (Figure 10). Coloration and bleaching kinetics for the studied PTR-Br samples are shown in Figure 11. The amplitude of UV-induced absorbance increased with the $\mathrm{Na}^{+}-\mathrm{Ag}^{+}$ IE time as the concentration of the embedded silver ions determined concentration and distribution of $\mathrm{AgBr}$ nanocrystals formed during the subsequent heat treatment. It should be noted that saturation of coloration was observed already after $100 \mathrm{~s}$ of UV irradiation for samples ion-exchanged for $0.25,1$, and $9 \mathrm{~h}$, while the sample ion-exchanged for $21 \mathrm{~h}$ did not show saturation even after $1000 \mathrm{~s}$ of UV irradiation.

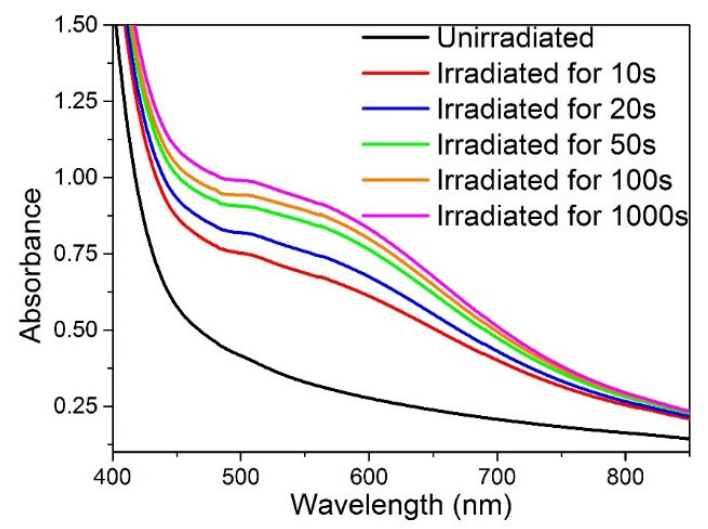

Figure 10. Absorbance spectra of the PTR-Br glass sample ion-exchanged for $9 \mathrm{~h}$ and heat-treated at $500{ }^{\circ} \mathrm{C}$ for $9 \mathrm{~h}$ after irradiation with UV pulses for different times.

After coloration by the UV pulsed laser, samples were kept at room temperature to study bleaching kinetics. Only partial bleaching of the samples was observed, while a number of color centers were stable at room temperature. For the samples ion-exchanged for $0.25,1$, and $9 \mathrm{~h}$, the absorbance increment reached $20-30 \%$ of the peak value after $72 \mathrm{~h}$ of relaxation. At the same time, the sample ion-exchanged for $21 \mathrm{~h}$ possessed a $45 \%$ decrease in absorbance.

The observed differences in coloration and bleaching kinetics of the ion-exchanged samples with $\mathrm{AgBr}$ nanocrystals may be explained by the different thickness of the glass layer doped with the nanocrystals and by size effect. According to Araujo, the mean size of silver halide nanocrystals in photochromic glasses is $8-18 \mathrm{~nm}$ because smaller particles exhibit low coloration efficiency [47]. Thus, the low saturation level in the samples ionexchanged for $15 \mathrm{~min}$ and $1 \mathrm{~h}$ can be explained by small $\mathrm{AgBr}$ nanocrystals with a mean size of 5 and $6 \mathrm{~nm}$, respectively, calculated according to the Scherrer equation. Partial bleaching of the studied samples resulted from the absence of polyvalent ions, for example, 
copper, that participate in redox reactions occurring in conventional photochromic glasses during coloration and bleaching [45,47]. It should be noted that full relaxation of color centers induced by a UV mercury lamp and UV pulsed laser was observed after heating PTR-Br glass samples above $150{ }^{\circ} \mathrm{C}$ for $10-15 \mathrm{~min}$.

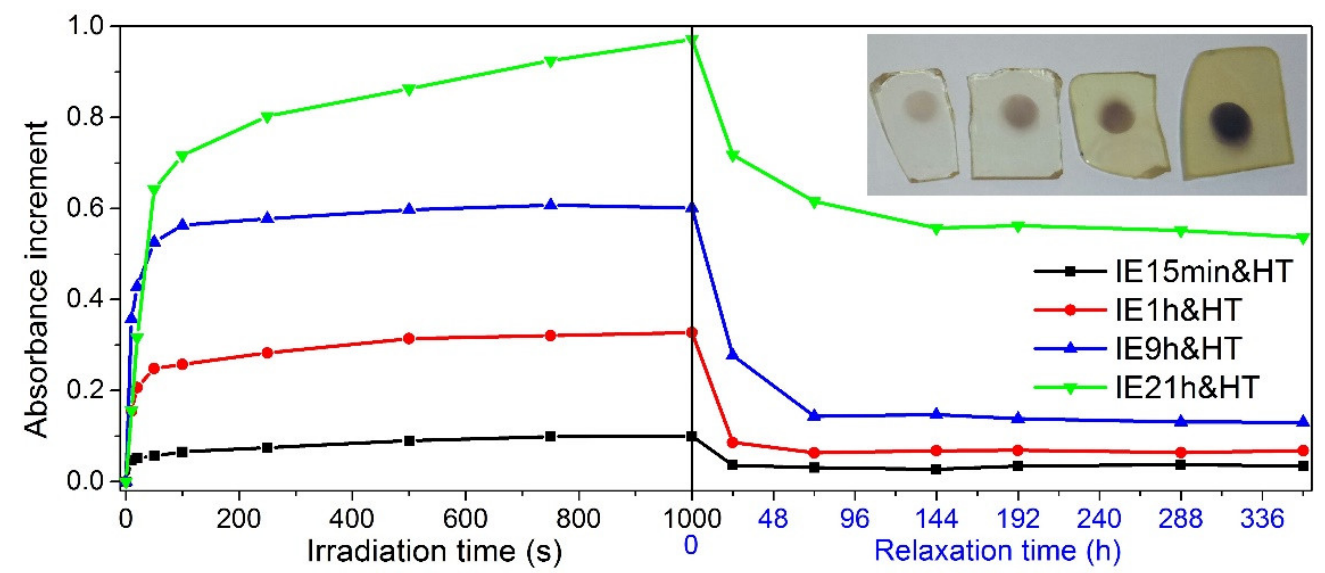

Figure 11. Coloring and bleaching kinetics for PTR-Br glass sample ion exchanged for different time and heat-treated at $500{ }^{\circ} \mathrm{C}$ for $9 \mathrm{~h}$. Inset: photo of the samples after irradiation by the UV pulsed laser during $1000 \mathrm{~s}$.

Silver bromide is an indirect semiconductor with direct and indirect band gap energies $\mathrm{E}_{\mathrm{g} \text {,dir }}=4.276 \mathrm{eV}$ and $\mathrm{E}_{\mathrm{g}, \text { ind }}=2.713 \mathrm{eV}$ for bulk crystals at cryogenic temperatures [48]. The energy bandgap of a semiconductor depends on temperature and decreases with its increase. In situ measurements of absorbance spectra revealed that the UV absorption edge of silver bromide nanocrystals formed in PTR-Br glass shifted to a greater wavelength with heating the sample (Figure 12). The effect was manifested as colored PTR-Br glass samples due to increasing absorption in the blue range (Figure 12, inset). After cooling the sample to room temperature and removing SNIF formed during the heating, the spectrum returned to the initial state. Figure 13a shows the dependence of the location of the UV absorption edge on the temperature of the samples ion-exchanged for different time. The experimental data can be fitted using a straight line for all samples. Moreover, for a wide temperature range between 300 and $500{ }^{\circ} \mathrm{C}$, absorbance at a fixed wavelength linearly depends on the temperature for samples ion-exchanged for 1 and $9 \mathrm{~h}$ (Figure 13b). Thus, the thermochromic properties of PTR-Br glass samples containing AgBr nanocrystals can be used as temperature sensors or an eye-readable overheating indicator. It should be noted that chlorine-doped PTR glass samples with $\mathrm{AgCl}$ nanocrystals formed with the $\mathrm{Na}^{+}-\mathrm{Ag}^{+}$IE were also studied. However, the photo- and thermochromic properties of PTR glass samples with $\mathrm{AgCl}$ nanocrystals was poorer compared to their brominedoped counterparts.

\subsection{Luminescent Properties of Silver Molecular Clusters Formed in Ce-and Sb-Doped Glasses}

Silver molecular clusters (SMCs) are subnanometer silver aggregates that consist of several atoms/ions. SMCs are characterized by photoluminescence and do not possess plasmon resonance. Stabilized in different matrices, including liquids, polymers, glasses, and zeolites, SMCs are used for developing white LEDs [49], sensors [50], spectral converters [51,52], and data storage devices [53]. Glasses doped with SMCs attract particular attention due to transparency in a wide spectral range, high thermal stability, and excellent chemical durability. A PTR glass matrix transparent in the UV range opens the possibility to study the spectral properties of SMCs in details. To promote the growth of SMCs in the $\mathrm{Na}^{+}-\mathrm{Ag}^{+}$ion-exchanged PTR glass, silver ions should be reduced to an atomic state. Cerium and antimony are polyvalent ions that can be in different charge states $\left(\mathrm{Ce}^{3+} / \mathrm{Ce}^{4+}\right.$ and $\left.\mathrm{Sb}^{3+} / \mathrm{Sb}^{5+}\right)$, which determines their spectroscopic manifestation in glass 
matrices $[54,55]$. These ions are typically used in PTR glasses to provide photosensitivity of the glass [3,4]. Possible redox reactions involving silver and cerium/antimony ions are as follows:

$$
\begin{aligned}
\mathrm{Ag}^{+}+\mathrm{Ce}^{3+} & \leftrightarrow \mathrm{Ag}^{0}+\mathrm{Ce}^{4+} \\
2 \mathrm{Ag}^{+}+\mathrm{Sb}^{3+} & \leftrightarrow 2 \mathrm{Ag}^{0}+\mathrm{Sb}^{5+}
\end{aligned}
$$

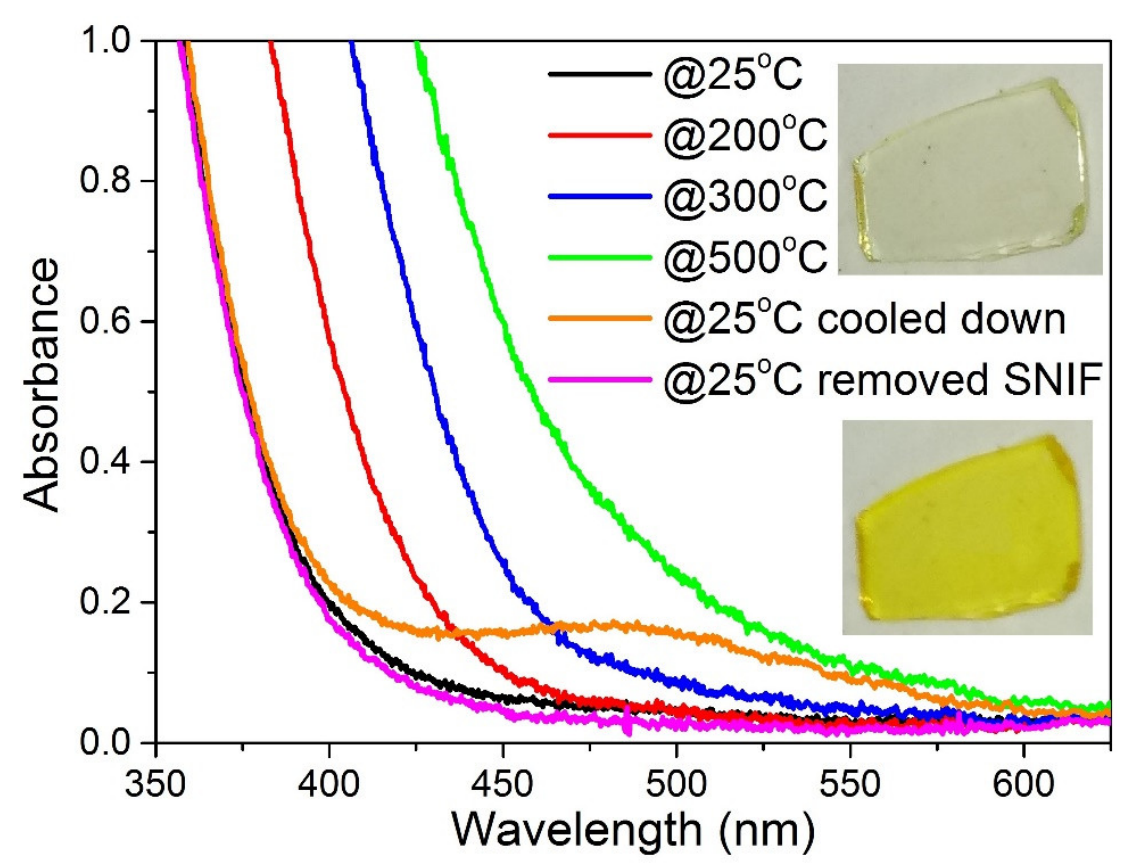

Figure 12. In situ absorbance spectra measured at different temperatures of PTR-Br glass sample ion-exchanged for $15 \mathrm{~min}$ and heat-treated at $500{ }^{\circ} \mathrm{C}$ for $9 \mathrm{~h}$. Inset: photos of the sample at room temperature (top image) and after pulling it out from a muffle furnace heated to $500{ }^{\circ} \mathrm{C}$ (bottom image).
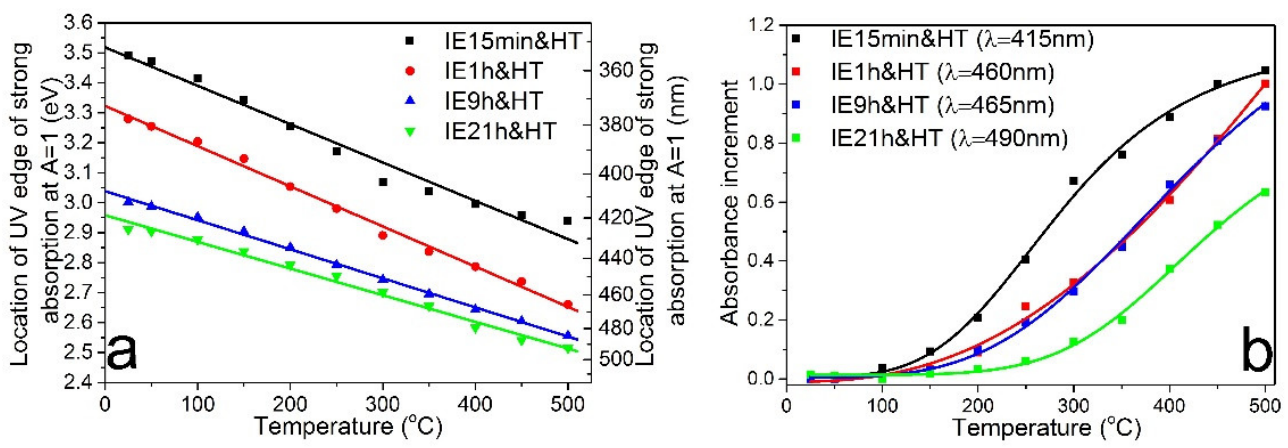

Figure 13. (a) Location of UV absorption edge and (b) absorbance increment at a fixed wavelength vs. temperature for PTR-Br glass samples ion-exchanged for different time and heat-treated at $500{ }^{\circ} \mathrm{C}$ for $9 \mathrm{~h}$.

To determine the direction of a redox reaction, one needs to know the value of the standard electrode potential. For example, the reaction in Equation (4) proceeds in standard conditions from right to left. Adding silver into the PTR glass matrix was earlier shown to result in a decrease in the $\mathrm{Ce}^{4+}$-related absorption band, proving that silver plays the role of a reducing agent for cerium ions in the PTR glass melt [56]. However, the concentration of $\mathrm{Ag}^{+}$ions in the ion-exchanged PTR glass layer exceeds by orders the equilibrium value that can be reached via glass synthesis, whereby the equilibria in Equations (4) and (5) shift to the right-hand side despite the direction of the reaction in standard conditions. Neutral silver atoms obtained as a result of the redox reactions can aggregate further in SMCs or 
NPs depending on their size. As shown below, the spectral luminescent properties of PTR $\mathrm{Na}^{+}-\mathrm{Ag}^{+}$ion-exchanged glass can be tuned in a wide range by varying the concentration of glass dopants, as well as the IE and subsequent heat treatment parameters.

The concentration of polyvalent ions determines the rate of the redox reaction with silver. Thus, a higher content of polyvalent ions allows a higher concentration of SMCs and SNPs to be obtained in glass at fixed parameters of the IE and heat treatment processes (Figure 14). It is worth noting that, for developing efficient phosphors or spectral converters based on a glass doped with SMCs, the concentration of polyvalent ions should be very low, so as to increase the possibility of SMCS growth consisting only of few atoms. In the other case, the growth of large clusters and/or SNPs results in luminescence quenching and a significant lowering of the photoluminescence quantum yield (PLQY). For example, a PLQY value as high as $65 \%$, which is among the highest reported values for glasses doped with SMCs [36], was achieved in PTR-Sb2 glass containing only $0.002 \mathrm{~mol} . \%$ of $\mathrm{Sb}_{2} \mathrm{O}_{3}$. An increase in $\mathrm{Sb}_{2} \mathrm{O}_{3}$ content to 0.01 mol.\% led to almost a twofold decrease in photoluminescence quantum yield.
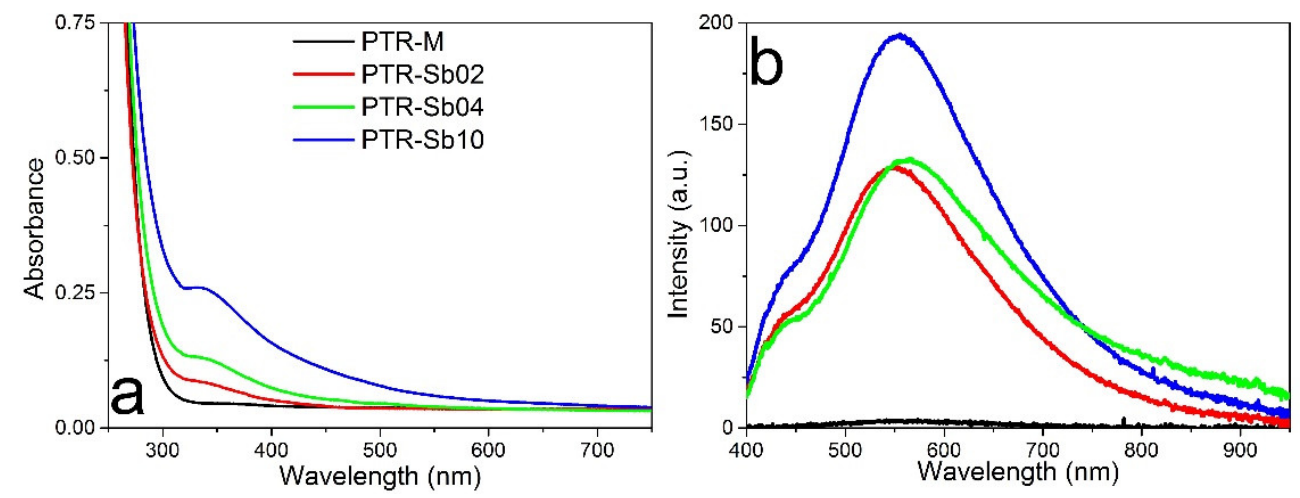

Figure 14. Absorbance (a) and emission (b) spectra of undoped PTR-M and antimony-doped PTR glass samples ion-exchanged for $15 \mathrm{~min}$ and heat-treated at $450^{\circ} \mathrm{C}$ for $15 \mathrm{~h}$. The excitation wavelength was $350 \mathrm{~nm}$.

Heat treatment at temperatures below the glass transition temperature was found to result in bright photoluminescence due to the growth of SMCs. PLQY magnitude increases with heat treatment temperature up to $450{ }^{\circ} \mathrm{C}$. Heat treatment at $500{ }^{\circ} \mathrm{C}$, i.e., above the $\mathrm{T}_{g}$ value of the studied antimony-doped glass samples, led to the appearance of an absorption band around $420 \mathrm{~nm}$ corresponding to the localized surface plasmon resonance of SNPs (Figure 15a). The growth of SNPs inevitably caused luminescence quenching due to the absorption of SMC emission and the decrease in concentration of emission centers due to the transformation of SMCs into SNPs (Figure 15b).
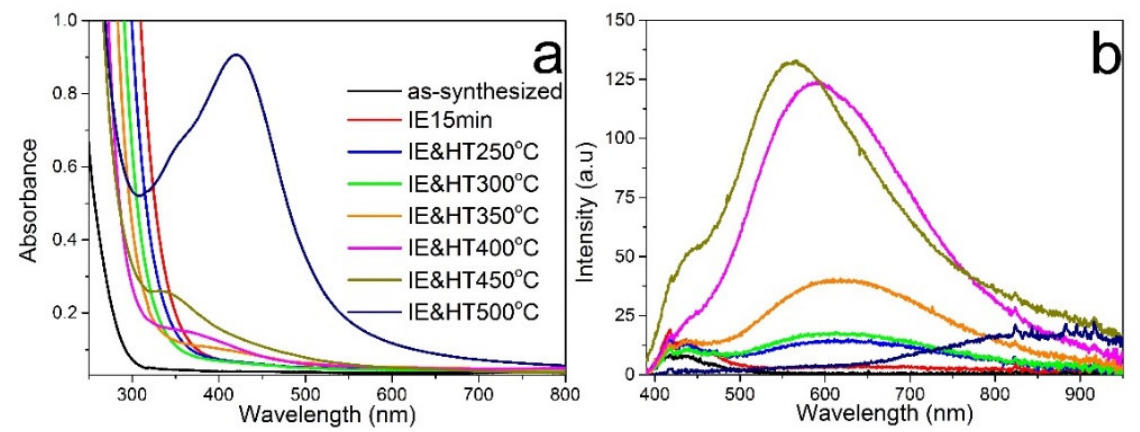

Figure 15. Absorbance (a) and emission spectra (b) of PTR-Sb10 glass samples as-synthesized, ionexchanged, and heat-treated after the IE process at different time for $15 \mathrm{~h}$. The excitation wavelength was $350 \mathrm{~nm}$. 
IE parameters, including silver content in the salt melt, temperature, and time, can also be used to tune the optical properties of silver nanostructures in $\mathrm{Na}^{+}-\mathrm{Ag}^{+}$ion-exchanged glasses. The IE time and temperature influence the diffusion rate and, as a result, the thickness of the silver-enriched glass layer. Thus, these parameters change the properties of the obtained silver nanostructures in a similar way. It was found that varying IE time allows tuning the location of SMC emission in a wide spectral range. This opens up prospects for developing highly efficient, thermostable, solid-state LEDs based on PTR glasses with SMCs. The effect of the IE time on the absorbance and emission of SMCs is demonstrated in Figures 16 and 17. Emission color varied from cool white to warm and orange upon increasing the IE time (Figure 16c). It should be noted that the PLQY of the samples decreased from $60 \%$ to $15 \%$ with the extension of IE duration [37]. This effect is related to the increase in absorbance of the remaining silver ions at the excitation wavelength with an increase in the IE time (a longer IE process leads to a higher amount of silver remaining in ionic form in the PTR glass due to the constant concentration of reducing agent). However, we believe that PLQY values can be substantially increased by using a salt melt with low silver content. The silver concentration in subsurface layers of the $\mathrm{Na}^{+}-\mathrm{Ag}^{+}$ion-exchanged glass is known to nonlinearly depend on the silver content in the salt melt for most glasses. Typically, the surface concentration of silver grows exponentially with $\mathrm{AgNO}_{3}$ content below $5 \mathrm{~mol} . \%$ and saturates at greater values [57]. IE with a low silver content may allow decreasing the absorption of silver ions that remain in the PTR glass after the heat treatment.

The presented results show that the photoluminescence properties of SMCs in the PTR glass matrix can be tuned in a wide range by controlling the concentration of reducing agents, as well as the parameters of the $\mathrm{Na}^{+}-\mathrm{Ag}^{+} \mathrm{IE}$ and subsequent heat treatment processes. The wide emission spectrum of SMCs in the ion-exchanged PTR glass matrix and the high PLQY magnitude pave the way for applications of such glasses in lighting as phosphors for white LEDs and in photovoltaics as spectral converters.
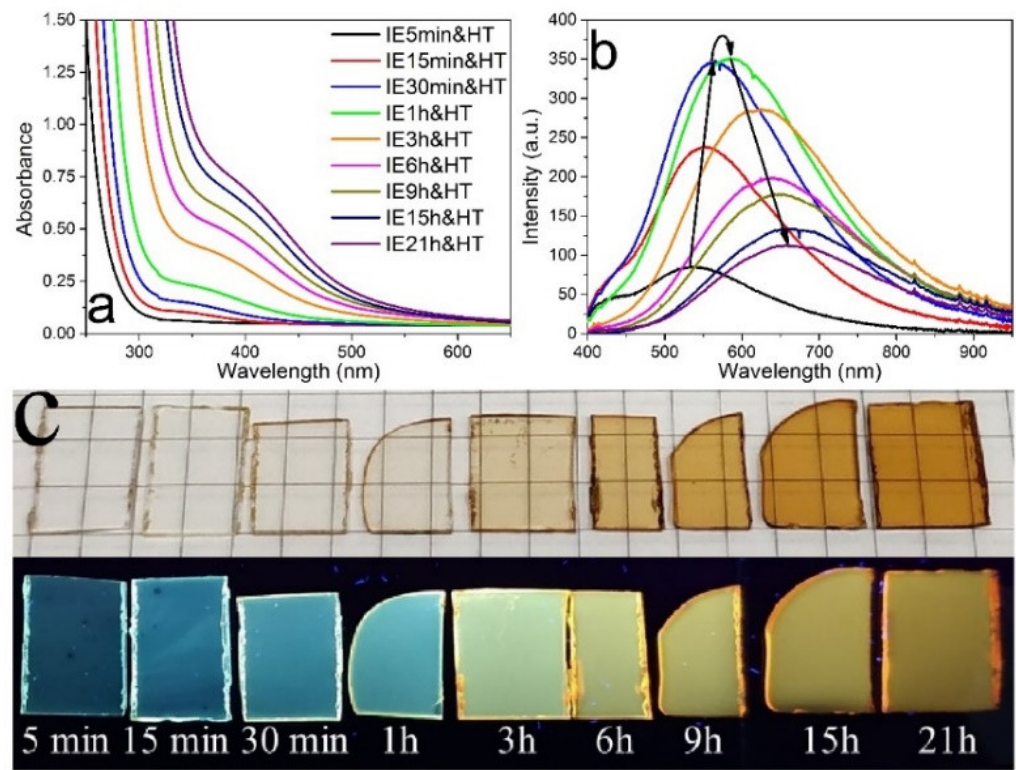

Figure 16. Absorbance (a) and emission (b) spectra of PTR-Sb2 glass samples ion-exchanged for different time and heat-treated at $450{ }^{\circ} \mathrm{C}$ for $15 \mathrm{~h}$. The excitation wavelength was $350 \mathrm{~nm}$. (c) Photo of the same samples in daylight (top row) and UV light (bottom row). 


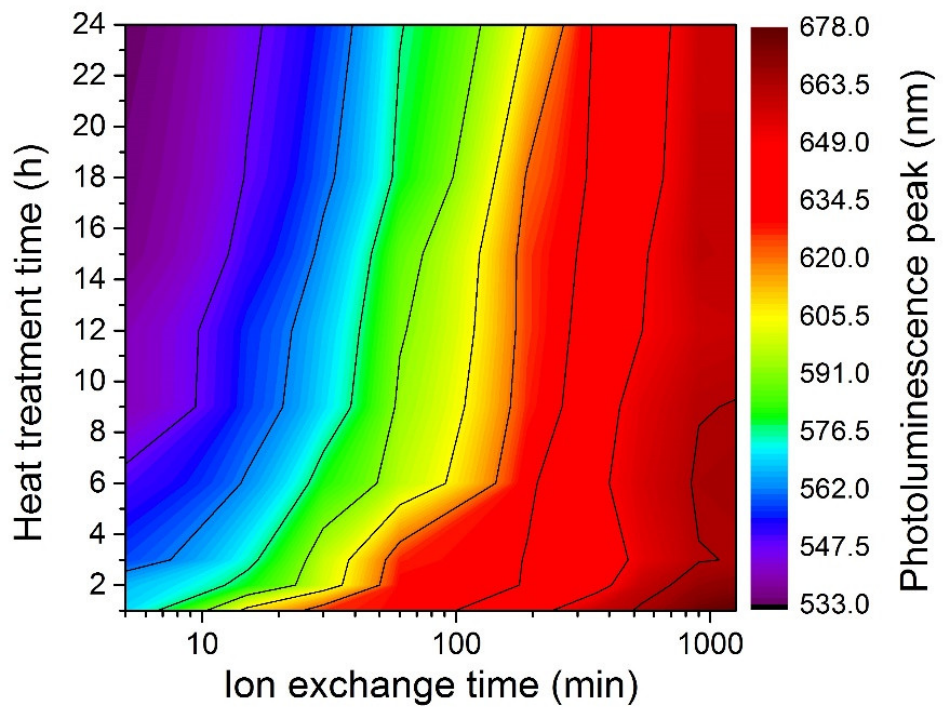

Figure 17. Dependence of photoluminescence peak location of PTR-Sb2 glass samples on the time of $\mathrm{Na}^{+}-\mathrm{Ag}^{+} \mathrm{IE}$ and subsequent heat treatment at $450{ }^{\circ} \mathrm{C}$.

\section{Conclusions and Perspectives}

In this work, the great effect of small additives in sodium-zinc-alumina glass composition on the spectral and optical properties of silver nanostructures grown on the surface or subsurface layers of $\mathrm{Na}^{+}-\mathrm{Ag}^{+}$ion-exchanged glasses was demonstrated. Silver ions introduced in the PTR glass matrix containing no polyvalent ions can interact with the atmosphere water molecules during heat treatment to form SERS-active silver nanoisland films on the glass surface. Trivalent cerium and antimony ions typically used as photosensitive additives in PTR glasses were shown to act as reducing agents for silver ions in $\mathrm{Na}^{+}-\mathrm{Ag}^{+}$ion-exchanged glasses and to promote the formation of luminescent silver molecular clusters. The concentration of polyvalent ions, as well as the ion exchange and subsequent heat treatment parameters, can be used to tune and optimize the emission of silver molecular clusters in a wide range.

$\mathrm{Na}^{+}-\mathrm{Ag}^{+}$ion exchange of $\mathrm{Br}(\mathrm{Cl})$-containing PTR glass followed by heat treatment above the glass transition temperature led to the growth of silver bromide nanocrystals. The obtained nano-glass ceramic possesses photochromic and thermochromic properties. The presented experimental findings indicate that small additives contained in glass play a key role in the chemical reactions with silver ions introduced by $\mathrm{Na}^{+}-\mathrm{Ag}^{+}$ion exchange and determine the properties of the obtained silver nanostructures and functionality of nano-glass ceramics. We believe that the results of this work can be useful for developing biochemical sensors based on the SERS phenomenon, white LEDs, spectral converters, and temperature sensors.

Author Contributions: Conceptualization, Y.S. and N.N.; formal analysis, Y.S.; funding acquisition, N.N.; investigation, Y.S.; methodology, Y.S. and A.I.; project administration, N.N.; validation, Y.S., N.N. and A.I.; writing—original draft, Y.S.; writing-review and editing, N.N. and A.I. All authors have read and agreed to the published version of the manuscript.

Funding: This work was financially supported by the Russian Science Foundation (Project \# 20-19-00559).

Institutional Review Board Statement: Not applicable.

Informed Consent Statement: Not applicable.

Data Availability Statement: Data is contained within the article.

Acknowledgments: The authors are thankful to Oreshkina K.S. for XRD measurements and Klyukin D.A. for SEM images.

Conflicts of Interest: The authors declare no conflict of interest. 


\section{References}

1. Nikonorov, N.; Aseev, V.; Dubrovin, V.; Ignatiev, A.; Ivanov, S.; Sgibnev, Y.; Sidorov, A. Photonic, Plasmonic, Fluidic, and Luminescent Devices Based on New Polyfunctional Photo-Thermo-Refractive Glass. In Optics, Photonics and Laser Technology; Ribeiro, P., Raposo, M., Eds.; Springer International Publishing: Berlin/Heidelberg, Germany, 2018; p. 246, ISBN 978-3-319-98547-3.

2. Nikonorov, N.; Ivanov, S.; Dubrovin, V.; Ignatiev, A. New Photo-Thermo-Refractive Glasses for Holographic Optical Elements: Properties and Applications. In Holographic Materials and Optical Systems; Naydenova, I., Ed.; IntechOpen: London, UK, 2017 ; p. 503.

3. Lumeau, J.; Zanotto, E.D. A review of the photo-thermal mechanism and crystallization of photo-thermo-refractive (PTR) glass. Int. Mater. Rev. 2017, 62, 348-366. [CrossRef]

4. Ivanov, S.; Dubrovin, V.; Nikonorov, N.; Stolyarchuk, M.; Ignatiev, A. Origin of refractive index change in photo-thermo-refractive glass. J. Non. Cryst. Solids 2019, 521, 119496. [CrossRef]

5. Sato, Y.; Taira, T.; Smirnov, V.; Glebova, L.; Glebov, L. Continuous-wave diode-pumped laser action of Nd ${ }^{3+}$-doped photo-thermorefractive glass. Opt. Lett. 2011, 36, 2257-2259. [CrossRef]

6. Ivanov, S.A.; Lebedev, V.F.; Ignat'ev, A.I.; Nikonorov, N.V. Laser action on neodymium heavily doped photo-thermo-refractive glass. In Proceedings of the 1st International Symposium on Advanced Photonic Materials, St. Petersburg, Russia, 27 June-1 July; ITMO University: St. Petersburg, Russia, 2016; pp. 29-31.

7. Sgibnev, Y.; Nikonorov, N.; Ignatiev, A.; Vasilyev, V.; Sorokina, M. Photostructurable photo-thermo-refractive glass. Opt. Express 2016, 24, 4563. [CrossRef]

8. Sgibnev, Y.M.; Nikonorov, N.V.; Vasilev, V.N.; Ignatiev, A.I. Optical Gradient Waveguides in Photo-Thermo-Refractive Glass Formed by Ion Exchange Method. J. Light. Technol. 2015, 33, 3730-3735. [CrossRef]

9. Stepanov, A.L.; Hole, D.E.; Townsend, P.D. Formation of silver nanoparticles in soda-lime silicate glass by ion implantation near room temperature. J. Non. Cryst. Solids 1999, 260, 65-74. [CrossRef]

10. Arnold, G.W.; Borders, J.A. Aggregation and migration of ion-implanted silver in lithia-alumina-silica glass. J. Appl. Phys. 1977, 48, 1488-1496. [CrossRef]

11. Onbaşl1, M.C.; Tandia, A.; Mauro, J.C. Mechanical and compositional design of high-strength Corning Gorilla ${ }^{\circledR}$ Glass. In Handbook of Materials Modeling: Applications: Current and Emerging Materials; Springer International Publishing: NewYork, NY, USA, 2020; pp. 1997-2019.

12. Findakly, T. Glass waveguides by ion exchange: A review. Opt. Eng. 1985, 25, 244-250. [CrossRef]

13. Tervonen, A.; West, B.R.; Honkanen, S. Ion-exchanged glass waveguide technology: A review. Opt. Eng. 2011, 50, 71107. [CrossRef]

14. Karlsson, S.; Jonson, B.; Stålhandske, C. The technology of chemical glass strengthening-A review. Glas. Technol. Eur. J. Glas. Sci. Technol. Part A 2010, 51, 41-54.

15. Haes, A.J.; Van Duyne, R.P. A nanoscale optical biosensor: Sensitivity and selectivity of an approach based on the localized surface plasmon resonance spectroscopy of triangular silver nanoparticles. J. Am. Chem. Soc. 2002, 124, 10596-10604. [CrossRef] [PubMed]

16. Fan, M.; Brolo, A.G. Silver Nanoparticles Self Assembly as SERS Substrates with Near Single Molecule Detection Limit. Phys. Chem. Chem. Phys. 2009, 11, 7381-7389. [CrossRef]

17. Enrichi, F.; Quandt, A.; Righini, G.C. Plasmonic enhanced solar cells: Summary of possible strategies and recent results. Renew. Sustain. Energy Rev. 2018, 82, 2433-2439. [CrossRef]

18. Ivanova, N.; Gugleva, V.; Dobreva, M.; Pehlivanov, I.; Stefanov, S.; Andonova, V. Silver Nanoparticles as Multi-Functional Drug Delivery Systems. In Nanomedicines; IntechOpen: London, UK, 2018.

19. Guo, H.; Feng, M.; Song, F.; Li, H.; Ren, A.; Wei, X.; Li, Y.; Xu, X. Q-switched Erbium-doped Fiber Laser Based on Silver Nanoparticles as a Saturable Absorber. IEEE Photonics Technol. Lett. 2015, 28, 135-138. [CrossRef]

20. Sarina, S.; Waclawik, E.R.; Zhu, H. Photocatalysis on Supported Gold and Silver Nanoparticles under Ultraviolet and Visible Light Irradiation. Green Chem. 2013, 17, 1814-1833. [CrossRef]

21. Fleischmann, M.; Hendra, P.J.; McQuillan, A.J. Raman spectra of pyridine adsorbed at a silver electrode. Chem. Phys. Lett. 1974, 26, 163-166. [CrossRef]

22. Doering, W.E.; Nie, S. Single-Molecule and Single-Nanoparticle SERS: Examining the Roles of Surface Active Sites and Chemical Enhancement. J. Phys. Chem. B 2002, 106, 311-317. [CrossRef]

23. Kneipp, J.; Kneipp, K. SERS-A single-molecule and nanoscale tool for bioanalytics. Chem. Soc. Rev. 2008, 37, 1052-1060. [CrossRef]

24. Chen, Y.; Karvonen, L.; Säynätjoki, A.; Ye, C.; Tervonen, A.; Honkanen, S. Ag nanoparticles embedded in glass by two-step ion exchange and their SERS application. Opt. Mater. Express 2011, 1, 164. [CrossRef]

25. Chen, Y.; Jaakola, J.J.; Säynätjoki, A.; Tervonen, A.; Honkanen, S. Glass-embedded silver nanoparticle patterns by masked ion-exchange process for surface-enhanced Raman scattering. J. Raman Spectrosc. 2011, 42, 936-940. [CrossRef]

26. Zhurikhina, V.V.; Brunkov, P.N.; Melehin, V.G.; Kaplas, T.; Svirko, Y.; Rutckaia, V.V.; Lipovskii, A.A. Self-assembled silver nanoislands formed on glass surface via out-diffusion for multiple usages in SERS applications. Nanoscale Res. Lett. 2012 , 7, 676. [CrossRef]

27. Chervinskii, S.; Sevriuk, V.; Reduto, I.; Lipovskii, A. Formation and 2D-patterning of silver nanoisland film using thermal poling and out-diffusion from glass. J. Appl. Phys. 2013, 114, 224301. [CrossRef] 
28. Heisler, F.; Babich, E.; Scherbak, S.; Chervinskii, S.; Hasan, M.; Samusev, A.; Lipovskii, A.A. Resonant Optical Properties of Single Out-Diffused Silver Nanoislands. J. Phys. Chem. C 2015, 119, 26692-26697. [CrossRef]

29. Babich, E.S.; Redkov, A.V.; Reduto, I.V.; Scherbak, S.A.; Kamenskii, A.N.; Lipovskii, A.A. Raman enhancement by individual silver hemispheroids. Appl. Surf. Sci. 2017, 397, 119-124. [CrossRef]

30. Cattaruzza, E.; Mardegan, M.; Trave, E.; Battaglin, G.; Calvelli, P.; Enrichi, F.; Gonella, F. Modifications in silver-doped silicate glasses induced by ns laser beams. Appl. Surf. Sci. 2011, 257, 5434-5438. [CrossRef]

31. Ajami, A.; Husinsky, W.; Svecova, B.; Vytykacova, S.; Nekvindova, P. Saturable absorption of silver nanoparticles in glass for femtosecond laser pulses at $400 \mathrm{~nm}$. J. Non. Cryst. Solids 2015, 426, 159-163. [CrossRef]

32. Sgibnev, E.M.; Ignatiev, A.I.; Nikonorov, N.V.; Efimov, A.M.; Postnikov, E.S. Effects of silver ion exchange and subsequent treatments on the UV-VIS spectra of silicate glasses. I. Undoped, CeO2-doped, and (CeO $2+\mathrm{Sb} 2 \mathrm{O} 3)$-codoped photo-thermorefractive matrix glasses. J. Non. Cryst. Solids 2013, 378, 213-226. [CrossRef]

33. Kinnan, M.K.; Chumanov, G. Plasmon Coupling in Two-Dimensional Arrays of Silver Nanoparticles: II. Effect of the Particle Size and Interparticle Distance. J. Phys. Chem. C 2010, 114, 7496-7501. [CrossRef]

34. Spierings, G. Optical absorption of Ag+ ions in 11(Na, Ag)2O·11B2O3.78SiO2 glass. J. Non. Cryst. Solids 1987, 94, 407-411. [CrossRef]

35. Efimov, A.M.; Ignatiev, A.I.; Nikonorov, N.V.; Postnikov, E.S. Ultraviolet-VIS spectroscopic manifestations of silver in photothermo-refractive glass matrices. Eur. J. Glas. Sci. Technol. Part A 2013, 54, 155-164.

36. Sgibnev, Y.M.; Nikonorov, N.V.; Ignatiev, A.I. High efficient luminescence of silver clusters in ion-exchanged antimony-doped photo-thermo-refractive glasses: Influence of antimony content and heat treatment parameters. J. Lumin. 2017, 188, 172-179. [CrossRef]

37. Sgibnev, Y.; Asamoah, B.; Nikonorov, N.; Honkanen, S. Tunable photoluminescence of silver molecular clusters formed in $\mathrm{Na}+\mathrm{Ag}+$ ion-exchanged antimony-doped photo-thermo-refractive glass matrix. J. Lumin. 2020, 226, 117411. [CrossRef]

38. Luo, W.; Hu, W.; Xiao, S. Size effect on the thermodynamic properties of silver nanoparticles. J. Phys. Chem. C 2008, 112, 2359-2369. [CrossRef]

39. Asoro, M.A.; Damiano, J.; Ferreira, P.J. Size effects on the melting temperature of silver nanoparticles: In-situ TEM observations. Microsc. Microanal. 2009, 15, 706-707. [CrossRef]

40. Zhao, S.J.; Wang, S.Q.; Cheng, D.Y.; Ye, H.Q. Three distinctive melting mechanisms in isolated nanoparticles. J. Phys. Chem. B 2001, 105, 12857-12860. [CrossRef]

41. Kumbhar, A.S.; Kinnan, M.K.; Chumanov, G. Multipole plasmon resonances of submicron silver particles. J. Am. Chem. Soc. 2005, 127, 12444-12445. [CrossRef]

42. Kaganovskii, Y.; Mogilko, E.; Lipovskii, A.A.; Rosenbluh, M. Formation of nanoclusters in silver-doped glasses in wet atmosphere. J. Phys. Conf. Ser. 2007, 61, 508-512. [CrossRef]

43. Araujo, R. Colorless glasses containing ion-exchanged silver. Appl. Opt. 1992, 31, 5221. [CrossRef]

44. Tutihasi, S. Optical absorption by silver halides. Phys. Rev. 1954, 105, 882-884. [CrossRef]

45. Dotsenko, L.B.; Glebov, V.A.T. Physics and Chemistry of Photochromic Glasses; CRC Press: Boca Raton, FL, USA, 1998.

46. Garfinkel, H.M. Photochromic glass by silver ion exchange. Appl. Opt. 1968, 7, 789-794. [CrossRef]

47. Araujo, R.J. Photochromic Glass. Treatise Mater. Sci. Technol. 1977, 12, 91-122. [CrossRef]

48. Madelung, O. Semiconductors: Data Handbook; Springer: Berlin/Heidelberg, Germany, 2004; ISBN 9783662036488.

49. Kuznetsov, A.S.; Tikhomirov, V.K.; Moshchalkov, V.V. UV-driven efficient white light generation by Ag nanoclusters dispersed in glass host. Mater. Lett. 2013, 92, 4-6. [CrossRef]

50. Dubrovin, V.D.; Ignatiev, A.I.; Nikonorov, N.V.; Sidorov, A.I.; Shakhverdov, T.A.; Agafonova, D.S. Luminescence of silver molecular clusters in photo-thermo-refractive glasses. Opt. Mater. Amst. 2014, 36, 753-759. [CrossRef]

51. Cattaruzza, E.; Caselli, V.M.; Mardegan, M.; Gonella, F.; Bottaro, G.; Quaranta, A.; Valotto, G.; Enrichi, F. Ag+↔Na+ ion exchanged silicate glasses for solar cells covering: Down-shifting properties. Ceram. Int. 2015, 41, 7221-7226. [CrossRef]

52. Sgibnev, Y.; Cattaruzza, E.; Dubrovin, V.; Vasilyev, V. Photo-Thermo-Refractive Glasses Doped with Silver Molecular Clusters as Luminescence Downshifting Material for Photovoltaic Applications. Part. Part. Syst. Charact. 2018, 35, 1800141. [CrossRef]

53. Bourhis, K.; Royon, A.; Papon, G.; Bellec, M.; Petit, Y.; Canioni, L.; Dussauze, M.; Rodriguez, V.; Binet, L.; Caurant, D.; et al. Formation and thermo-assisted stabilization of luminescent silver clusters in photosensitive glasses. Mater. Res. Bull. 2013, 48, 1637-1644. [CrossRef]

54. Efimov, A.M.; Ignatiev, A.I.; Nikonorov, N.V.; Postnikov, E.S. Quantitative UV-VIS spectroscopic studies of photo-thermorefractive glasses. II. Manifestations of $\mathrm{Ce} 3+$ and $\mathrm{Ce}(\mathrm{IV})$ valence states in the UV absorption spectrum of cerium-doped photo-thermo-refractive matrix glasses. J. Non. Cryst. Solids 2013, 361, 26-37. [CrossRef]

55. Ehrt, D. Photoluminescence in the UV-VIS region of polyvalent ions in glasses. J. Non. Cryst. Solids 2004, 348, 22-29. [CrossRef]

56. Efimov, A.M.; Ignatiev, A.I.; Nikonorov, N.V.; Postnikov, E.S. Photo-Thermo-Refractive Glasses: Effects of Dopants on Their Ultraviolet Absorption Spectra. Int. J. Appl. Glas. Sci. 2015, 6, 109-127. [CrossRef]

57. Zhurikhina, V.V.; Petrov, M.I.; Sokolov, K.S.; Shustova, O.V. Ion-exchange characteristics of sodium-calcium-silicate glass: Calculation from mode spectra. Tech. Phys. 2010, 55, 1447-1452. [CrossRef] 